\title{
Inclusive Growth: Measurement and Determinants
}

Rahul Anand, Saurabh Mishra, and Shanaka J. Peiris 


\title{
IMF Working Paper
}

Asia Pacific Department

\section{Inclusive Growth: Measurement and Determinants}

\author{
Prepared by Rahul Anand, Saurabh Mishra, and Shanaka J. Peiris *
}

Authorized for distribution by Paul Cashin

May 2013

\section{This Working Paper should not be reported as representing the views of the IMF. The views expressed in this Working Paper are those of the author(s) and do not necessarily represent those of the IMF or IMF policy. Working Papers describe research in progress by the author(s) and are published to elicit comments and to further debate.}

\begin{abstract}
We estimate a unified measure of inclusive growth for emerging markets by integrating their economic growth performance and income distribution outcomes, using data over three decades. Country distributions are calibrated by combining PPP GDP per capita and income distribution from survey data. We apply the microeconomic concept of a social mobility function at the macroeconomic level to measure inclusive growth that is closer to the absolute definition of propoor growth. This dynamic measure permits us to focus on inequality as well as distinguish between countries where per capita income growth was the same for the top and the bottom of the income pyramid, by accounting for the pace of growth. Our results indicate that macroeconomic stability, human capital, and structural changes are foundations for achieving inclusive growth. The role of globalization could also be positive with foreign direct investment and trade openess fostering greater inclusiveness, while financial deepening and technological change have no discernible effect.
\end{abstract}

JEL Classification Numbers: F43, D63, O11, O47

Keywords: economic growth, pro-poor growth, distribution, equity, inequality, inclusive growth Authors’ E-Mail Addresses: ranand@imf.org, smishra2@,imf.org, speiris@imf.org

\footnotetext{
* We are grateful to Paul Cashin, Romain Duval, Rachel Van Elkan, Davide Furceri, Florence Jaumotte, Kalpana Kochhar, Prakash Loungani, Branko Milanovic, Chris Papageorgiou, Laura Papi, and Hans Weisfeld for valuable comments. We received helpful comments from conference participants at the $37^{\text {th }}$ Annual Conference of the Federation of ASEAN Economics Association, Manila. Any errors are solely ours.
} 


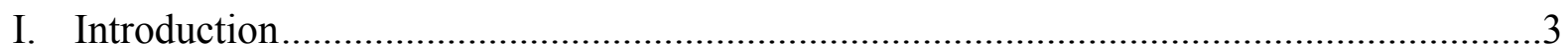

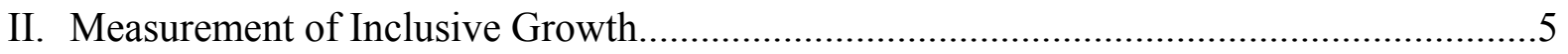

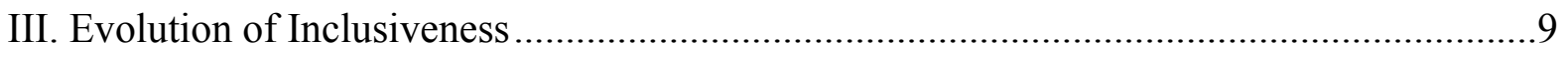

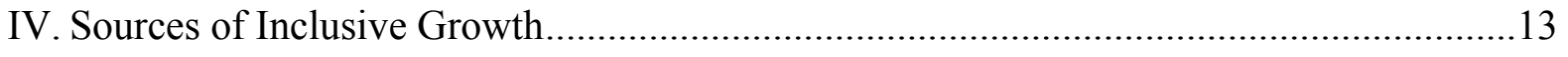

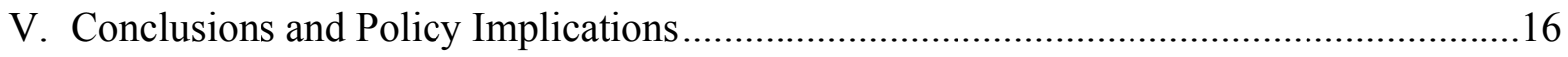

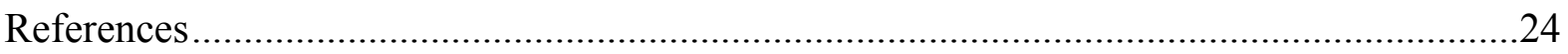

Figures

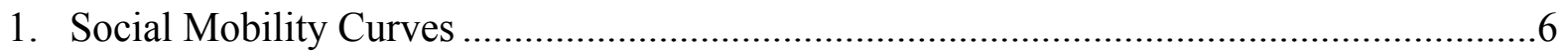

2. Shifts in Social Mobility Curve ...............................................................................

3. Distribution of Emerging Markets on Inclusiveness Matrix......................................... 10

4. Indifference Curves for Selected Emerging Markets................................................... 12

Tables

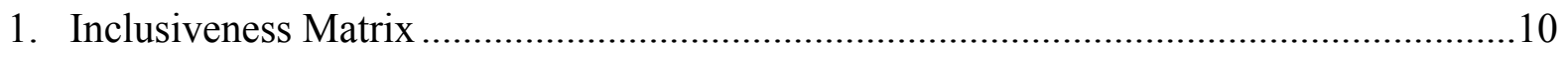

2. Panel Regression: Emerging Markets................................................................... 15

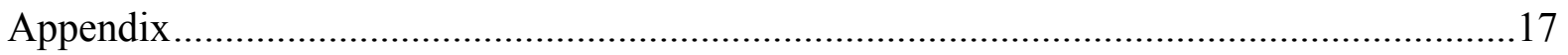




\section{INTRODUCTION}

Our measure of inclusive growth refers to both the pace and distribution of economic growth. In order for growth to be sustainable and effective in reducing poverty, it needs to be inclusive (Berg and others 2011a; Kraay, 2004). The Commission on Growth and Development 2008 notes that inclusiveness - a concept that encompasses equity, equality of opportunity, and protection in market and employment transitions - is an essential ingredient of any successful growth strategy. However, attempts to measure inclusive growth have remained limited. Traditionally, poverty (or inequality) and economic growth analyses have been done separately. ${ }^{1}$ Recent work indicates that there may not be a trade-off between equity and efficiency as suggested by Okun (1975) and "that it would be a big mistake to separate analyses of growth and income distribution" (see Berg and Ostry, 2011b). This paper attempts to integrate the two strands of analyses by developing a unified measure of inclusive growth. Ianchovichina and Gable (2011) explain inclusive growth as about raising the pace of growth and enlarging the size of the economy by providing a level playing field for investment and increasing productive employment opportunities.

\section{Our measure of inclusive growth is in line with the absolute definition of pro-poor} growth, but not the relative definition. Under the absolute definition, growth is considered to be pro-poor as long as poor people benefit in absolute terms, as reflected in some agreed measures of poverty (Ravallion and Chen, 2003). In contrast, under the relative definition, growth is pro-poor if and only if the incomes of poor people grow faster than those of the population as a whole; that is, inequality declines (Dollar and Kraay, 2002; IMF 2011). By focusing on inequality, the relative definition could lead to suboptimal outcomes for both poor and non-poor households. ${ }^{2}$ For example, a society attempting to achieve pro-poor growth under the relative definition would favor an outcome characterized by average income growth of 2 percent where the income of poor households grew by 3 percent, over an outcome where average growth was 6 percent, but the incomes of poor households grew by only 4 percent. Our dynamic measure of inclusive growth permits us to focus on inequality but distinguish between countries where per capita income growth was the same for the top and the bottom of the pyramid by accounting for the pace of growth. ${ }^{3}$

\section{A recent flurry of media and political attention toward rising inequality across the globe has generated a tremendous amount of interest on its causes and consequences. While the rise in inequality in the OECD and some emerging markets is well documented,}

\footnotetext{
${ }^{1}$ See, for example, IMF (2007) and Barro and Lee (1995).

${ }^{2}$ To that effect it is important to clarify the distinction between inequalities of outcomes versus inequalities of opportunities. The focus of this empirical study looks at ex post inequality i.e. inequality of outcome.

${ }^{3}$ Such a measure has a stronger correlation with poverty than per capita income or inequality alone (see Appendix Figure A2).
} 
there is debate on the causes and even more controversy on the consequences and what should be done about it. A number of recent papers have associated the rising inequality with technological change, financial deepening, and certain aspects of globalization (Acemoglu, and Autor, 2011; Aizeman, Lee, and Park 2012; and IMF 2007). ${ }^{4}$ This is almost certainly the highest level of relative, and certainly absolute, global inequality at any point in human history, which may threaten the foundations of the social order (see Milanovic 2010). The welfare considerations of high inequality extend beyond the effect on growth and macroeconomic stability, but it remains relevant to understand whether macroeconomic fundamentals and structural change (broadly defined) affect inclusive growth. For example, current debate on austerity and growth or recent calls to slow the pace of financial deepening and globalization may reduce income inequality but could slow inclusive growth as well. It is vital to assess the dynamics and determinants of inclusive growth, keeping in mind that the goal of reducing inequality is not to hurt the rich at the expense of the poor. ${ }^{5,6}$

\section{A unified measure of inclusive growth allows us to identify its determinants and prioritize country-specific constraints to build inclusive growth. To do this, Section II} develops a measure of inclusive growth using a macro social mobility function, following the micro literature on income distribution. Section III documents the evolution of inclusive growth focusing on emerging markets and low income countries, whereas most previous studies only cover OECD countries. ${ }^{7}$ Section IV examines the sources of inclusive growth in emerging markets and low income countries, as well as some supporting evidence from advanced economies.

This paper makes three contributions to the inclusive growth debate. First, the paper develops a unified macro measure of inclusive growth, which integrates growth and income

\footnotetext{
${ }^{4}$ Foreign trade can exacerbate inequality by rewarding industries and firms which are able to compete in the global marketplace while punishing those which cannot. Technological progress has also been widely put forth as a structural driver of inequality. Skilled workers are better able to adopt and use new, improved technology than other unskilled workers, thereby increasing the skill premium and widening the wage gap between skilled and unskilled workers. The divide between Main Street and Wall Street epitomizes the recent thinking on the role of financial deepening in fueling inequity.

${ }^{5}$ Inclusive growth has been thought of bringing with it a bigger middle class and efficient re-allocation of resources and reducing 'information asymmetry'. Inclusive growth can conceptually also be thought beyond traditional lines of poverty change and should also reflect changes in the size and distribution neither poor nor rich - that is, the middle class (see Birdsall 2009).

${ }^{6}$ For example, the initial reforms that ignited growth in China involved giving stronger incentives to farmers. This increased the income of the poor and reduced overall inequality/poverty through time as it gave a spur to growth. However, it probably led to some increased inequality among farmers, and efforts to resist this component of inequality would likely have been counterproductive (see Chauffeur and Ravallion, 2007).

${ }^{7}$ The Appendix also presents the evolution of inclusive growth in a few advanced economies to assess whether it matches with our more established views on income dynamics in OECD economies.
} 
distribution into one single measure. To the best of our knowledge, this is the first unified measure of inclusive growth applied in a cross-country context. Our measure provides a framework to study equity and efficiency together. Second, the measure is used to study the dynamics and determinants of inclusive growth in low income countries and emerging markets. Third, the paper tries to uncover the relation between inclusive growth, and macroeconomic fundamentals including macro stability and competitiveness, and structural change encompassing globalization or growing integration into global trade and financial system.

\section{MEASUREMENT OF INCLUSIVE GROWTH}

To integrate equity and growth in a unified measure, we propose a measure of inclusive growth based on a utilitarian social welfare function drawn from consumer choice literature, where inclusive growth depends on two factors: (i) income growth; and (ii) income distribution. Similar to the consumer theory where the indifference curves represent the changes over time in aggregate demand, we decompose the income and substitution effect into growth and distributional components. The underlying social welfare function must satisfy two properties to capture these features: (i) it is increasing in its argument (to capture growth dimension) and (ii) it satisfies the transfer property - any transfer of income from a poor person to a richer person reduces the value of the function (to capture distributional dimension).

A measure of inclusiveness is based on the concept of a concentration curve. ${ }^{8}$ Following Ali and Son (2007), we define a generalized concentration curve, which we call social mobility curve, $S^{C}$, such that:

$$
S^{C} \approx\left(y_{1}, \frac{y_{1}+y_{2}}{2}, \ldots \ldots \ldots, \frac{y_{1}+y_{2}+\cdots y_{n}}{n}\right)
$$

Where $\mathrm{n}$ is the number of persons in the population with incomes $y_{1}, y_{2}, \ldots \ldots, y_{n}$, where $y_{1}$ is the poorest person and $y_{n}$ is the richest person. ${ }^{9}$

This generalized concentration curve is basically a cumulative distribution of a social mobility vector $S \approx\left(y_{1}, y_{2}, y_{3}, \ldots \ldots, y_{n}\right)$ with an underlying function $W=W\left(y_{1}, y_{2}, \ldots \ldots, y_{n}\right)$ satisfying the two properties mentioned above to capture growth and distribution dimensions. Since $S^{C}$ satisfies the transfer property, a superior income distribution will always have a higher generalized concentration curve. Similarly, since it is

\footnotetext{
${ }^{8}$ See Kakwani (1980) for detailed discussions on the concentration curve.

${ }^{9}$ See Ali and Son (2007) for details.
} 
increasing in its argument, higher income will also have a higher generalized concentration curve.

As in Ali and Son (2007), the generalized concentration curves can be presented in continuous time to be more amendable to econometric analysis. The population is arranged in the ascending order of their income. Let $\bar{y}_{i}$ is the average income of the bottom $i$ percent of the population, where $i$ varies from 0 to 100 and $\bar{y}$ is the mean income. We plot $\bar{y}_{i}$ for different values of $i$ (curve $\mathrm{AB}$ in figure 1 below). Curve $\mathrm{AB}$ represents a social mobility curve discussed above. Since a higher curve implies greater social mobility, growth is inclusive if the social mobility curve moves upward at all points. However, there may be degrees of inclusive growth depending on: (i) how much the curve moves up (growth); and (ii) how the distribution of income changes (equity). This feature of the social mobility curve is the basis of our integrated measure of inclusive growth. Thus, if two generalized concentration curves do not intersect, they could be ranked on social mobility i.e. inclusiveness of growth.

To illustrate the point made above, Figure 1 depicts two social mobility curves with the same average income $(\bar{y})$ but different degrees of inclusiveness (i.e. different income distribution). Social mobility curve (A1B) is more inclusive than the social mobility curve AB, as the average income of the bottom segment of the society is higher.

\section{Figure 1. Social Mobility Curves}

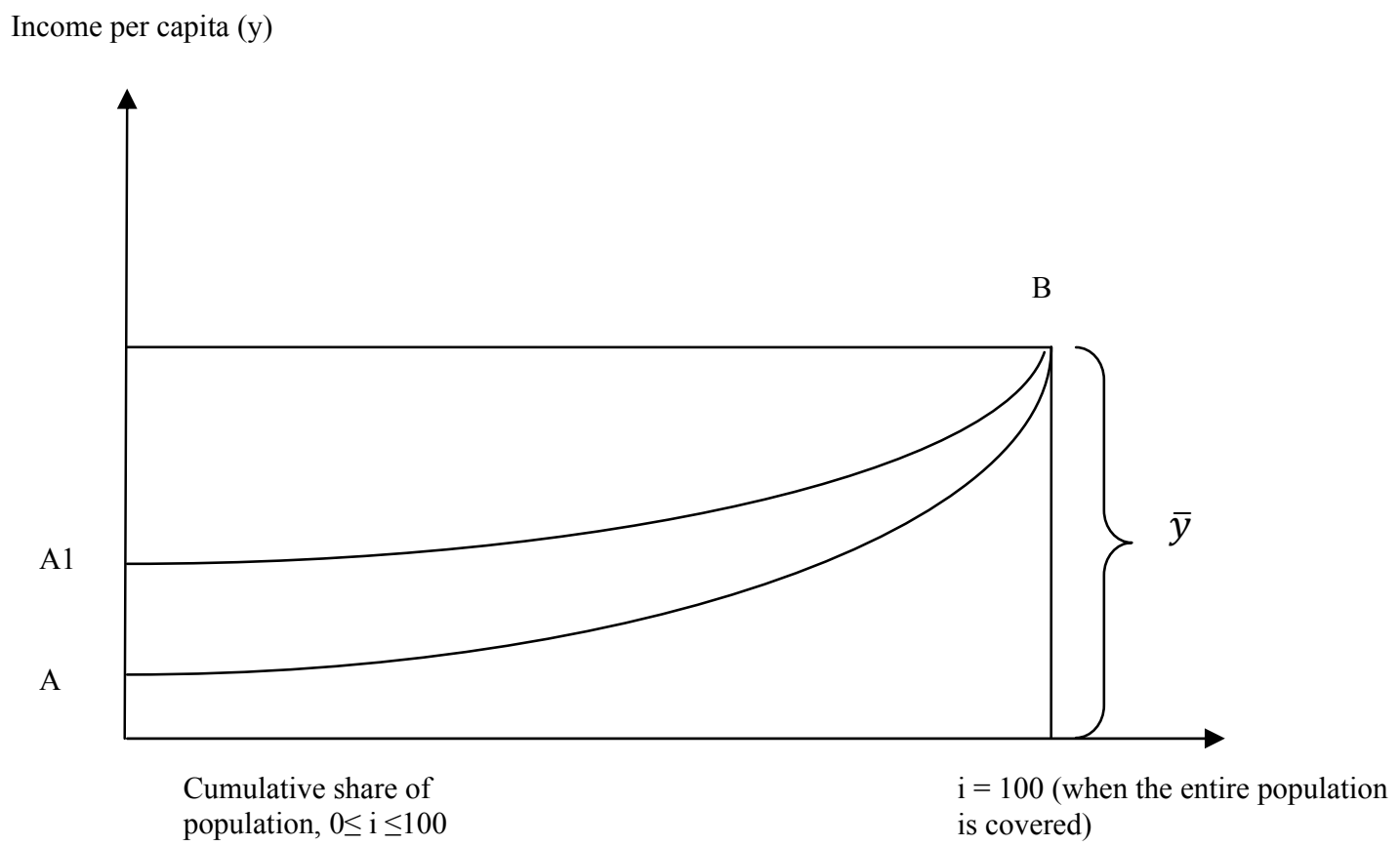


To capture the magnitude of the change in income distribution, we use a simple form of the social mobility function by calculating an index (or social mobility index) from the area under the social mobility curve:

$$
\bar{y}^{*}=\int_{0}^{100} \bar{y}_{i} d i
$$

The greater the $\bar{y}^{*}$, the greater is the income. If the income of everyone in the population is same (i.e. if income distribution is completely equitable) then $\bar{y}^{*}$ will be equal to $\bar{y}$. If $\bar{y}^{*}$ is lower than $\bar{y}$, it implies that the distribution of income is inequitable. So, the deviation of $\bar{y}^{*}$ from $\bar{y}$ is an indication of inequality in income distribution.

Ali and Son (2007 use this feature of $\bar{y}^{*}$ and propose an income equity index (IEI) as:

$$
\omega=\frac{\bar{y}^{*}}{\bar{y}}
$$

For a completely equitable society, $\omega=1$. Thus, higher value of $\omega$ (closer to one) represents higher income equality. Rearranging,

$$
\bar{y}^{*}=\omega * \bar{y}
$$

Inclusive growth requires increasing $\bar{y}^{*}$, which could be achieved by: (i) increasing $\bar{y}$, i.e increasing average income through growth; (ii) increasing the equity index of income, $\omega$, through increasing equity; or (iii) a combination of (i) and (ii). Differentiating the above equation:

$$
d \bar{y}^{*}=\omega * d \bar{y}+d \omega * \bar{y}
$$

Where $d \bar{y}^{*}$ is the change in the degree of inclusive growth. ${ }^{10}$ Growth is more inclusive if $d \bar{y}^{*}>0$. It also allows us to decompose inclusive growth into income growth and change in equity. The first term is the contribution of increase in average income (keeping income distribution constant) while the second term is the contribution of changes in the income distribution (keeping the average income unchanged).

Inclusive growth depends on the sign and the magnitude of the two terms. Graphically, Figure 2 below illustrates all possible combinations of the two terms. If both terms are positive $(d \bar{y}>0, d \omega>0)$, growth is unambiguously inclusive (AB shifting to A1B1 in Figure 2); similarly, if both terms are negative $(d \bar{y}<0, d \omega<0)$, growth is unambiguously non-inclusive (AB shifting to A4B4). However, there could be tradeoff between $\bar{y}$ and $\omega$. If

\footnotetext{
${ }^{10}$ Inclusive growth is defined as the change in the social mobility index $d \bar{y}^{*}$, which we use interchangeably.
} 
the first term is positive but the second term is negative, higher social mobility is achieved at the expense of reduction in equity; in Figure 2, this case can be illustrated by the shift of the social mobility curves from AB to A2B2. Similarly, if the first term is negative but the second term is positive, then higher social mobility is achieved at the cost of contraction in average income: in Figure 2, this case can be illustrated by the shift of the social mobility curve from $\mathrm{AB}$ to $\mathrm{A} 3 \mathrm{~B} 3$.

\section{Figure 2. Shifts in Social Mobility Curve}

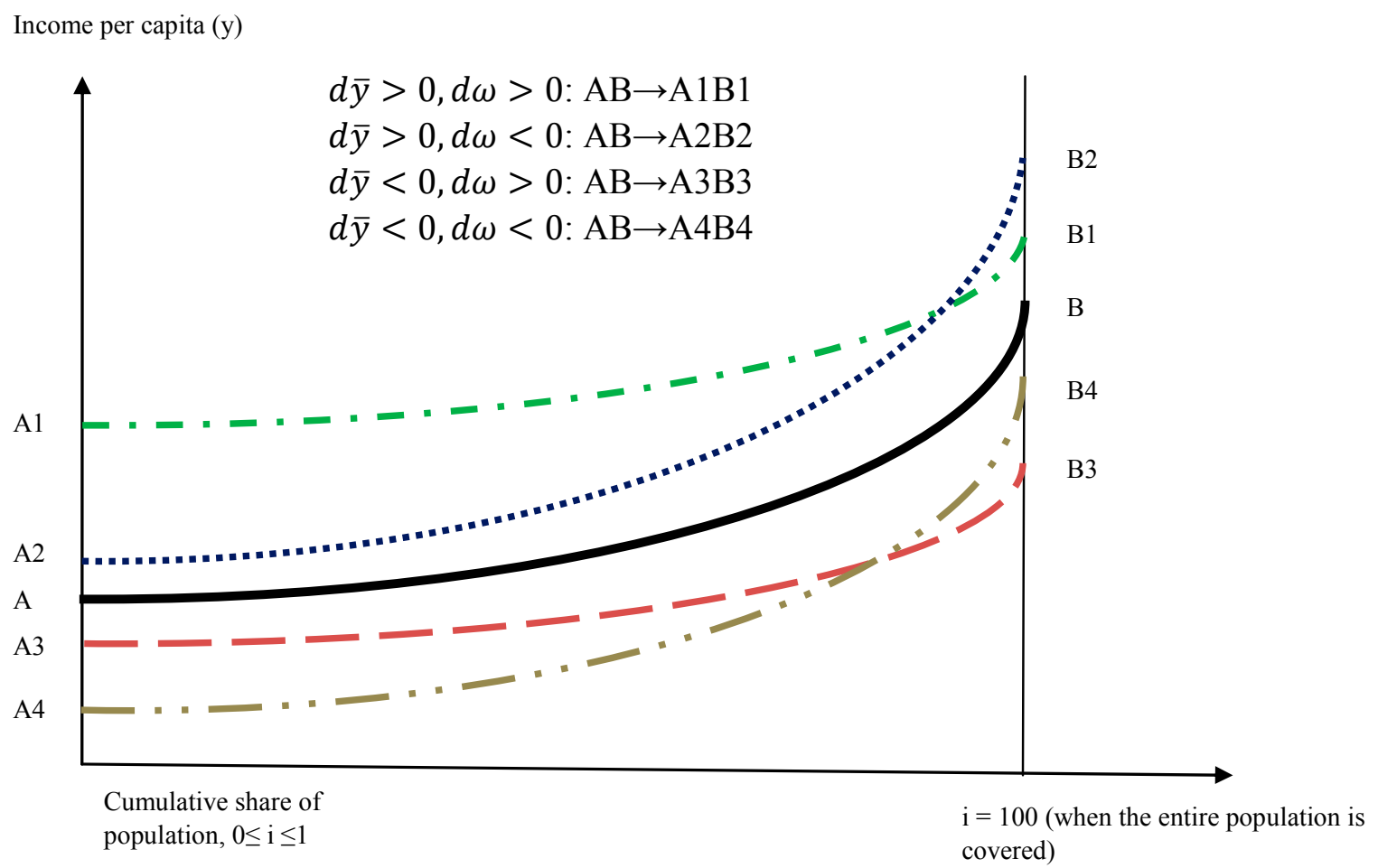

Equation (2) could also be rearranged as:

$$
\frac{d \bar{y}^{*}}{\bar{y}^{*}}=\frac{d \bar{y}}{\bar{y}}+\frac{d \omega}{\omega}
$$

This is the fundamental relation integrating growth and equity into one measure of inclusive growth (percent change in $\bar{y}^{*}$ ). It decomposes inclusive growth into growth and percentage change in equity, measured by $\omega$. We use this decomposition in the subsequent sections to illustrate the evolution of inclusive growth and the relative contributions of growth and equity. While the use of a simple form of the social mobility function by calculating a social mobility index from the area under the social mobility curve is intuitive and consistent with the absolute definition of pro-poor growth, we could also assign different weights to the 
growth and equity dimensions to introduce more subjective views on inclusive growth. ${ }^{11}$ However, sensitivity analysis shows that moderate changes to the weighting of growth and equity dimensions do not significantly alter the ranking of countries or dynamics of inclusive growth across the globe.

\section{EVOLUTION OF INCLUSIVENESS}

Relatively few countries have achieved strong inclusive growth. Previous studies have focused on the convergence (or lack thereof) of the distribution of income across the world (see Dollar and Kray 2006; Sala-i-Martin, 2006) or the rising level of inequality (see IMF 2007). We shed light on both those aspects by mapping out the change in inclusiveness or social mobility across countries over the last few decades. While cross-country comparisons of inequality are generally plagued by problems of poor data reliability, lack of coverage, and inconsistent methodology, we rely on income distribution data from the latest World Bank Povcal database constructed by Chen and Ravallion (2004) for a large number of emerging markets using a more rigorous approach to filtering the individual income and consumption data for differences in quality than other commonly used databases. ${ }^{12}$ Given that inclusive growth levels (or $\bar{y}^{*}$ ) are country-specific, this section focuses instead on percentage changes for cross-country comparisons, where increasing $\bar{y}^{*}$ is associated with greater inclusiveness.

\section{The limited gains in inclusiveness are explained by relatively low growth in some} countries and widening inequality in others. A decomposition of inclusiveness following equation (2) shows that there is a wide dispersion of outcomes. There are four possible scenarios (Table 1), but as depicted in Figure 3 most countries fall in the two quadrants that show higher per capita income and a lower/or higher level of inequity, suggesting that there is no simple trade-off between growth and equality. A global heat map (Appendix Figure 1) shows that very few countries have achieved a rapid pace of inclusive growth (e.g., China) while others have seen relatively modest gains. At first glance, it may seem odd that China performs so well in a measure of inclusive growth. Although rapid economic growth has been achieved at the expense of somewhat rising inequality, all income quintiles have unambiguously benefitted more than any other country in the post-WWII period.

\footnotetext{
${ }^{11}$ It should be noted that our inclusive growth measure already assigns a decreasing weight to higher income groups. For example, if we transfer a dollar from the 10th decile to 1 st decile, inclusiveness $\left(\bar{y}^{*}\right)$ and equity $(\omega)$ increase by more than if we transfer a dollar from 10th decile to 2 nd decile and so on.

${ }^{12}$ The data cover 143 countries during 1980-2010, with the number of observations varying by country and variable. The average income for deciles is calculated using the quintile income-share data and real GDP per capita (in 2000 international dollars chain-series). Income shares are multiplied by the GDP per capita variable and divided by the population share to arrive at the average income per decile. See IMF (2007) for more discussion of the data limitations.
} 


\section{Table 1. Inclusiveness Matrix}

\begin{tabular}{lll}
\hline $\boldsymbol{d} \overline{\boldsymbol{y}}>\mathbf{0}$ & $d \omega>0$ & Unambiguously Inclusive \\
\hline $\boldsymbol{d} \overline{\boldsymbol{y}}>\mathbf{0}$ & $d \omega<0$ & $\begin{array}{l}\text { Higher per capita income at the expense of } \\
\text { equity (could be inclusive if the percentage } \\
\text { change in } \bar{y}>\text { the percent change in } \omega \text { (see } \\
\text { equation } 3 \text { above) }\end{array}$ \\
\hline $\boldsymbol{d} \overline{\mathbf{y}}<\mathbf{0}$ & $d \omega>0$ & $\begin{array}{l}\text { Equity objective is achieved at the cost of } \\
\text { average income contraction }\end{array}$ \\
\hline $\boldsymbol{d} \overline{\boldsymbol{y}}<\mathbf{0}$ & $d \omega<0$ & Unambiguously non-inclusive \\
\hline
\end{tabular}

Figure 3. Distribution of Emerging Markets on Inclusiveness Matrix

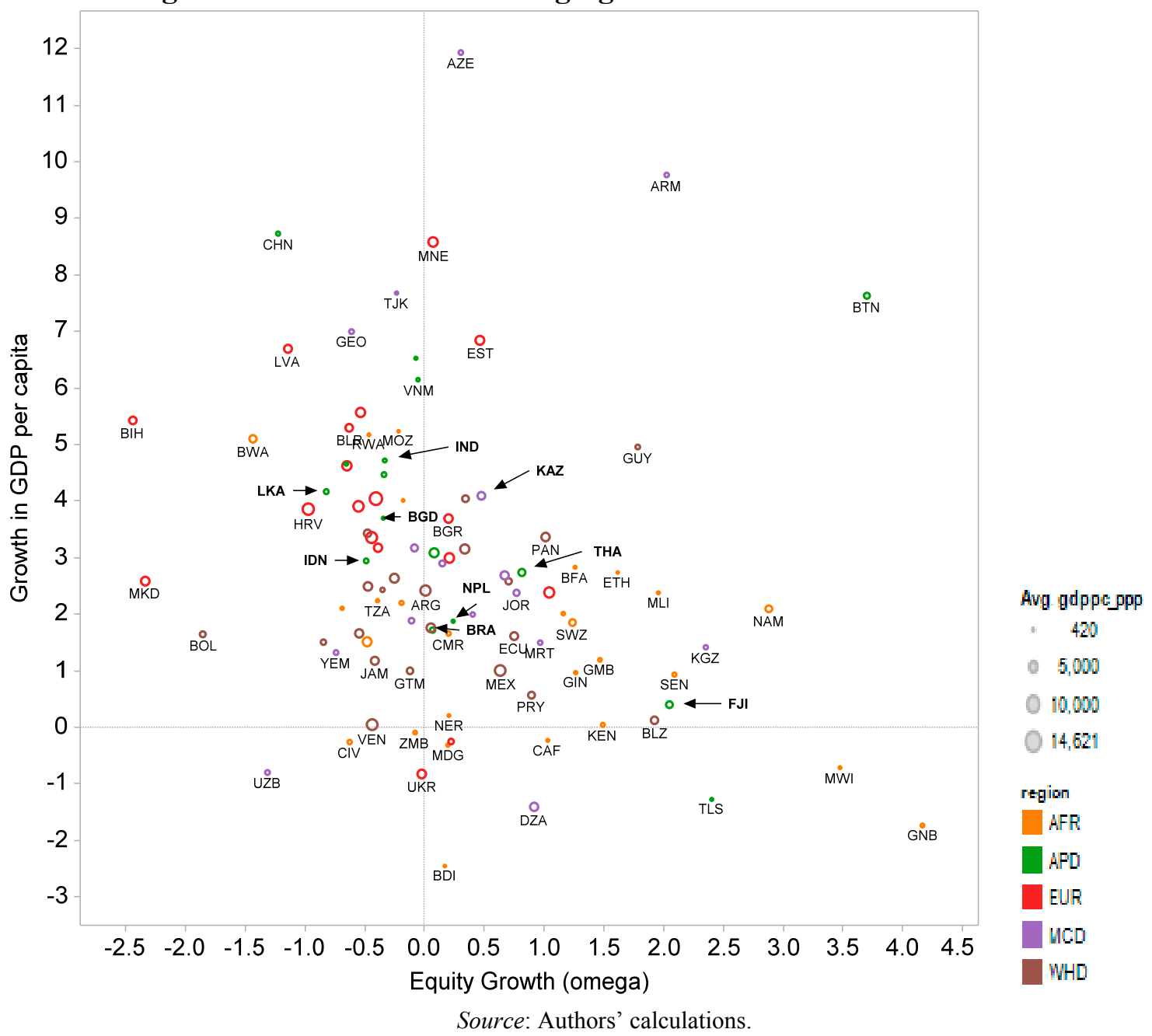

Note: The chart measures proportionate average annual change. The period used is from the early 1990s to the latest available data, see Table A1 for details on time periods chosen. Size represents the initial size of the economy (GDP per capita) i.e. the legend represents countries with PPP GDP per capita below 420, 5000, 10,000 and 14,621 respectively. Different regional codes are denoted by different colors. 
The matrix above and indifference curves provide a tool to analyze the evolution of inclusiveness across the globe through time. Figure 4 shows the indifference curves highlighting inclusiveness over time for a few selected emerging economies (i.e. Brazil, Malaysia, Mexico, Thailand, India and China). In all these cases, economic growth shifted the indifference curve upwards. However, the relatively magnitude of shift and curvature of indifference curves both matter. China's inclusive growth is primarily a growth story. Rapid growth in per capita income has benefitted everyone, but the gains have been much greater for the rich (as depicted by negative value on equity $(\omega)$ and steepening of the indifference curve). Thus, in China, high growth has eclipsed the growing inequality to produce a large upward shift of the indifference curve and greater $\bar{y}^{*}$. A similar story holds for India, where high growth has benefitted everyone, but equity has gone down. On other hand, the increase in inclusiveness in Brazil, Mexico, Malaysia and Thailand has come from both growth as well as improvement in equity (positive $\omega$ ) but growth has not been fast enough to benefit the entire population as much as China. ${ }^{13}$ Appendix Figure A3 documents similar shifts in social mobility in OECD countries for illustration.

Both economic growth and equity can be important to achieve inclusive growth. There is a continuum of inclusive growth ranging from pure income growth in China at one end, and zero income growth but a better distribution (like Kenya) at the other end of the spectrum. A country like India can be considered in between (closer to China), with a relatively lower decline in equity yet still high economic growth. Across emerging markets as a whole, the heterogeneity in economic growth performance and income distribution outcomes provide insight to the growth-equity tradeoff. Conventional wisdom suggests that growth comes at the price of rising inequality, but regions differ in their growth-equity trade off. In some instances high growth has been reached without compromising equity. Appendix Figure A4 presents similar orthogonal correlations as Figure 3, but with fitted trend lines for different regions. The slopes for Middle East and Central Asia and Western Hemisphere regions have a positive slope whereas other regions display a negative slope (even though there are exceptions within regions with outliers such as Bhutan or Mali). This analysis enforces the central message that both the magnitude and shift of incomes across population is important to achieve inclusive growth.

\footnotetext{
${ }^{13}$ Appendix Table A1 provides summary statistics for our calibration across Emerging Markets. Appendix Figure A5 decomposes inclusive growth into its growth and equity components for selected Emerging Markets.
} 
Figure 4. Indifference Curves for Selected Emerging Markets
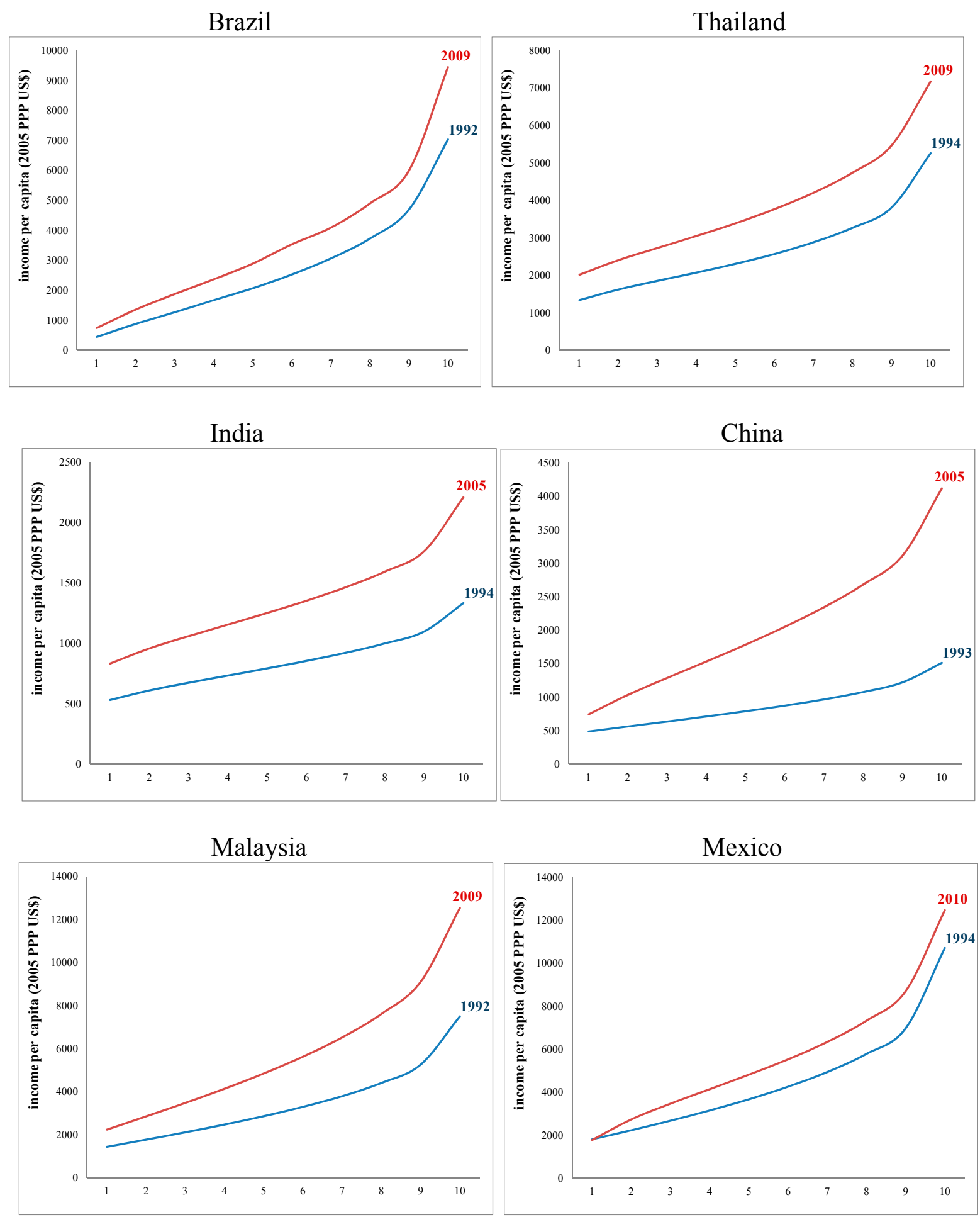


\section{SOURCES OF INCLUSIVE GROWTH}

While there is broad agreement on the basic policies that are important for growth and reducing poverty, little is known about what may foster inclusive growth. Rapid pace of growth is unquestionably necessary for substantial poverty reduction (see Kraay 2004, and Lopez and Servén, 2004), but for this growth to be sustainable in the long run, it should be broad-based across sectors and equitable (see Berg and Ostry, 2011a). This is all the more important since some of key determinants of growth (e.g., education, openness, financial depth) established in the literature (Barro and Lee, 2000; Dollar and Kraay, 2003; and Levine 2005) have been associated with higher inequality (Barro, 2000; and IMF, 2009), begging the question what proximate factors support inclusive growth.

Panel regressions of the unique measure of inclusive growth on a broad sample of emerging markets provide insights into the proximate determinants of inclusive growth. We explain our measure of inclusive growth or $\overline{\partial y^{*}}$ on a set of standard control variables used in cross-country growth and inequality literature in a non-overlapping unbalanced 5year panel of 143 countries from 1970-2010. Consider the following "standard" panel growth regression:

$$
Y_{i, t}^{*}-Y_{i, t-1}^{*}=\alpha_{0}+\beta_{1}^{\circ} \bar{Y}_{i, t}+\beta_{1}^{\circ} X_{i, t}+\eta_{c}+\gamma_{t}+\vartheta_{c, t}
$$

where $\mathrm{Y}^{*}{ }_{\mathrm{i}, \mathrm{t}}-\mathrm{Y}^{*}{ }_{\mathrm{i}, \mathrm{t}-1}$ is the $\log$-difference of $\overline{\mathrm{y}}^{*}$ or inclusive growth in country $i$ at time $t$, $\bar{Y}_{i, t}$ is the initial level of per capita PPP-adjusted income at the start of the 5-year panel period $t$ to reflect conditional convergence, and $\mathrm{X}_{\mathrm{i}, \mathrm{t}}$ is a set of growth and inequality determinants measured as averages over the 5-year panel period $t$. The disturbance term in the regression consists of an unobserved country effect $\left(\eta_{c}\right)$ that is constant over time and an unobserved period effect $\left(\gamma_{\mathrm{t}}\right)$ that is common across countries, and a component $\left(\vartheta_{\mathrm{c}, \mathrm{t}}\right)$ that varies across both countries and years which we assume to be uncorrelated over time.

\section{A number of macroeconomic fundamentals and structural factors are drivers of} inclusive growth. Consistent with results in Barro and Lee (2000), Dollar and Kraay (2003) and Ramey and Ramey (1995), Table 2 shows that lower initial incomes (conditional convergence), trade openness, fixed investment, moderate inflation and output volatility, and a better educated workforce have helped countries achieve more inclusive growth. ${ }^{14}$ FDI has a significantly positive impact on inclusive growth as in IMF (2007), while ICT in the total capital stock does not have a discernible impact; the latter could also reflect the lack of data on ICT investment data in many emerging markets and LICs. Financial openness more

\footnotetext{
${ }^{14}$ We also undertook robustness checks for education variables using Barro and Lee years of schooling in primary, secondary and tertiary education. All measures of education are statistically significant, with tertiary education attainment with highest magnitude. These results are not reported here.
} 
generally also shows a positive association with inclusive growth. Interestingly, financial deepening, measured by the credit-to-GDP ratio, has a negative impact as in IMF (2007), but is not statistically significant. This could be because inclusive growth encompasses both the pace and distribution of growth while previous findings such as Levine (2005) positively linked financial development to growth while IMF (2007) associated it with greater inequity. Structural transformation and moving up the value chain in both goods and services has also attracted lot of attention in terms of driving economic growth and inequity (Anand, Mishra and Spatafora, 2012; and Hausmann, Hwang, and Rodrik, 2007). Technological changes are increasingly making service activities more productive, fragmented in global supply chains and digitally tradable. In addition to modernizing manufacturing, the globalization of services is increasingly a driver of economic growth in emerging markets (see Mishra, Lundstrom and Anand, 2011). Our results illustrate that countries that upgraded either manufacturing or service sophistication had higher inclusive growth. The sophistication of services driven by globalization, in particular seems to have a greater impact on inclusive growth. The deviation of the REER from its PPP-implied level is negatively associated with inclusive growth, suggesting a role for competitiveness. Infrastructure quality, as measured by Calderon and Servén (2004) and Seneviratne and Sun (2013), also plays a positive role in fostering inclusive growth possibly by reducing the cost of doing business and creating employment. ${ }^{15}$ The importance of competitiveness through such indicators such the deviation of the REER from its PPP-implied level and infrastructure quality should be interpreted with caution given the limited observations. ${ }^{16}$

\section{A preliminary empirical analysis of inclusive growth in a sample of advanced economies in the pre-GFC period identifies a similar set of proximate determinants of inclusive growth (see Appendix Table A2). The standard economic growth determinants such as initial income, education levels, trade openness, fixed investment, government consumption and inflation are significant determinants of inclusive growth. However, FDI does not appear to play a positive role as in EMs as expected although ICT that is better measured than in EMs has a significantly positive impact on inclusive growth. Financial deepening and openness is not significant.}

\footnotetext{
${ }^{15}$ The lack of consistent unemployment data precluded the estimation of a link between employment and inclusive growth stressed by Ianchovichina and Gable (2011).

${ }^{16}$ The limited degrees of freedom precluded a comprehensive analysis of the robustness of the findings and thus are complemented by preliminary results on advanced economies in Appendix Table A2. Furthermore, the determinants of an inclusive growth measured with an arbitrarily greater weight on inequity do not fundamentally change the proximate determinants of the dynamic inclusive growth processes.
} 
Table 2. Panel Regression: Emerging Markets

Dependent Variable: Growth in $\bar{y}^{*}$ (inclusive growth)

\begin{tabular}{|c|c|c|c|c|c|c|c|}
\hline & (1) & (2) & (3) & (4) & (5) & (6) & (7) \\
\hline lag GDP per capita (logs) & $\begin{array}{l}-0.211^{* *} \\
(0.0904)\end{array}$ & $\begin{array}{l}-0.203^{*} \\
(0.107)\end{array}$ & $\begin{array}{c}-0.300^{* * * *} \\
(0.101)\end{array}$ & $\begin{array}{c}-0.468 * * * \\
(0.139)\end{array}$ & $\begin{array}{c}-0.605^{* * *} \\
(0.184)\end{array}$ & $\begin{array}{c}-0.528 * * \\
(0.198)\end{array}$ & $\begin{array}{c}-0.558^{* * *} \\
(0.145)\end{array}$ \\
\hline Education & $\begin{array}{c}0.397 * * * \\
(0.149)\end{array}$ & $\begin{array}{l}0.309^{*} \\
(0.180)\end{array}$ & $\begin{array}{c}0.120 \\
(0.205)\end{array}$ & $\begin{array}{l}0.261^{*} \\
(0.151)\end{array}$ & $\begin{array}{c}0.783 * * * \\
(0.280)\end{array}$ & $\begin{array}{c}0.173 \\
(0.220)\end{array}$ & $\begin{array}{l}0.560^{* *} \\
(0.235)\end{array}$ \\
\hline Trade Openness & $\begin{array}{c}0.246^{* *} \\
(0.1000)\end{array}$ & $\begin{array}{l}0.194 * \\
(0.114)\end{array}$ & $\begin{array}{l}-0.0442 \\
(0.120)\end{array}$ & $\begin{array}{c}0.418 * * * \\
(0.133)\end{array}$ & $\begin{array}{c}0.223 \\
(0.240)\end{array}$ & $\begin{array}{c}0.0130 \\
(0.0970)\end{array}$ & $\begin{array}{c}-0.00118 \\
(0.0943)\end{array}$ \\
\hline Credit-to-GDP & $\begin{array}{l}-0.160 \\
(0.144)\end{array}$ & $\begin{array}{l}-0.164 \\
(0.174)\end{array}$ & $\begin{array}{l}-0.0390 \\
(0.171)\end{array}$ & $\begin{array}{l}-0.0176 \\
(0.186)\end{array}$ & $\begin{array}{l}-0.0822 \\
(0.0946)\end{array}$ & $\begin{array}{c}0.112 \\
(0.146)\end{array}$ & $\begin{array}{l}-0.137 \\
(0.184)\end{array}$ \\
\hline Government Consumption & $\begin{array}{l}-0.718 \\
(0.866)\end{array}$ & $\begin{array}{l}-0.340 \\
(0.956)\end{array}$ & $\begin{array}{l}-0.394 \\
(0.731)\end{array}$ & $\begin{array}{c}0.367 \\
(0.616)\end{array}$ & $\begin{array}{c}-2.849 * * * \\
(0.571)\end{array}$ & $\begin{array}{c}-0.00748 \\
(1.003)\end{array}$ & $\begin{array}{l}-1.250 \\
(0.905)\end{array}$ \\
\hline Investment & $\begin{array}{l}0.949^{* *} \\
(0.438)\end{array}$ & $\begin{array}{c}1.030 \\
(0.646)\end{array}$ & $\begin{array}{c}0.945 \\
(0.582)\end{array}$ & $\begin{array}{c}0.786 \\
(0.650)\end{array}$ & $\begin{array}{c}-0.141 \\
(1.102)\end{array}$ & $\begin{array}{c}0.439 \\
(0.781)\end{array}$ & $\begin{array}{l}1.018^{* *} \\
(0.485)\end{array}$ \\
\hline Inflation & $\begin{array}{c}-0.0275^{*} \\
(0.0143)\end{array}$ & $\begin{array}{l}-0.0280^{*} \\
(0.0143)\end{array}$ & $\begin{array}{c}-0.0227^{*} \\
(0.0129)\end{array}$ & $\begin{array}{c}-0.0830^{* * *} \\
(0.0110)\end{array}$ & $\begin{array}{c}-0.0524 * * * \\
(0.00326)\end{array}$ & $\begin{array}{l}-0.00349 \\
(0.00270)\end{array}$ & $\begin{array}{l}-0.00129 \\
(0.00313)\end{array}$ \\
\hline GDP Volatility & $\begin{array}{c}-2.126^{* *} \\
(1.065)\end{array}$ & $\begin{array}{c}-2.175^{* *} \\
(1.076)\end{array}$ & $\begin{array}{l}-0.991 \\
(0.875)\end{array}$ & $\begin{array}{c}0.223 \\
(1.781)\end{array}$ & $\begin{array}{l}-1.604 \\
(2.065)\end{array}$ & $\begin{array}{c}-0.788 \\
(1.066)\end{array}$ & $\begin{array}{l}-1.235 \\
(1.042)\end{array}$ \\
\hline Financial Openness & & $\begin{array}{l}0.000547^{* *} \\
(0.000274)\end{array}$ & & & & & \\
\hline FDI & & & $\begin{array}{l}0.0101 * * * \\
(0.00248)\end{array}$ & & & & \\
\hline ICT & & & & $\begin{array}{l}-0.718 \\
(0.432)\end{array}$ & & & \\
\hline REER Deviations & & & & & $\begin{array}{c}-0.00245 * * * \\
(0.000779)\end{array}$ & & \\
\hline Infrastructure Quality & & & & & & $\begin{array}{c}0.131 * * * \\
(0.0385)\end{array}$ & \\
\hline Service export sophistication (logs) & & & & & & & $\begin{array}{c}0.500^{* * * *} \\
(0.165)\end{array}$ \\
\hline Goods export sophistication (logs) & & & & & & & $\begin{array}{l}0.390 * \\
(0.216)\end{array}$ \\
\hline Constant & $\begin{array}{l}5.123 * * \\
(2.167)\end{array}$ & $\begin{array}{l}4.899^{*} \\
(2.587)\end{array}$ & $\begin{array}{c}7.453 * * * \\
(2.443)\end{array}$ & $\begin{array}{c}12.06^{* * *} \\
(3.579)\end{array}$ & $\begin{array}{c}15.43^{* * * *} \\
(4.370)\end{array}$ & $\begin{array}{l}12.46^{* *} \\
(4.902)\end{array}$ & $\begin{array}{l}5.816^{* *} \\
(2.573)\end{array}$ \\
\hline Observations & 261 & 234 & 234 & 111 & 98 & 139 & 146 \\
\hline R-squared & 0.263 & 0.284 & 0.376 & 0.285 & 0.514 & 0.150 & 0.288 \\
\hline Number of countries & 99 & 89 & 89 & 36 & 63 & 49 & 58 \\
\hline
\end{tabular}




\section{Conclusions ANd Policy Implications}

The call for inclusive growth has been unanimously declared by policymakers across the world. The Arab Spring, the growing divide between Main Street and Wall Street in advanced economies, and the "three speed" world economy have placed inclusive growth at the forefront of policy debates.

We quantify and integrate two strands of the literature to define inclusive growth. This approach is in line with the absolute definition of pro-poor growth, and goes beyond just focusing on distribution issues. The integrated measure, developed in this paper, is useful to delve deeper into the pattern of inclusive growth and study the sources of inclusive growth. Our methodology directly links the micro and macro dimensions of inequality and growth to reflect both the pace and distribution of income growth.

Macroeconomic stability, human capital and structural changes are found to be key determinants of inclusive growth in emerging markets. The standard economic growth drivers in the literature such as conditional convergence, education levels, and fixed investment are important, while the role of technological change has a less discernible impact. In terms of structural change and globalization, trade openness and foreign direct investment (FDI) foster inclusive growth, with a potentially positive role played by financial openness. Moving up the value chain in both goods and service exports also helps foster inclusive growth. However, financial deepening could have a negative impact as in IMF (2007), although the impact is not statistically significant. Macroeconomic stability is reinforced as a key ingredient for inclusive growth. Competitiveness (measured by REER deviations from PPP) and infrastructure could also be important for inclusive growth, although the statistical evidence is weak.

\section{Looking forward, there are a number of unresolved issues and areas for future} research. Many countries responded to the Global Financial Crisis through large fiscal stimulus and/or bank bailouts, which are being withdrawn or are being met with growing austerity. The relation between fiscal consolidation and inclusive growth is worthy of further study. The availability of more granular data will be important to analyze the evolution of inclusive growth at the national and sub-national levels across regions. Secondly, the speed of technological advancement, its reach and access, and the channels through which it can foster or hinder inclusive growth, is another area for future research. Lastly, with respect to job creation, it will be relevant to better understand the links between unemployment and labor market institutions that foster inclusive growth. 
APPENDiX

Figure A1. Evolution of Inclusiveness across the Globe (Percentage change in $\bar{y}^{*}$, intensity (green - high, red - low)

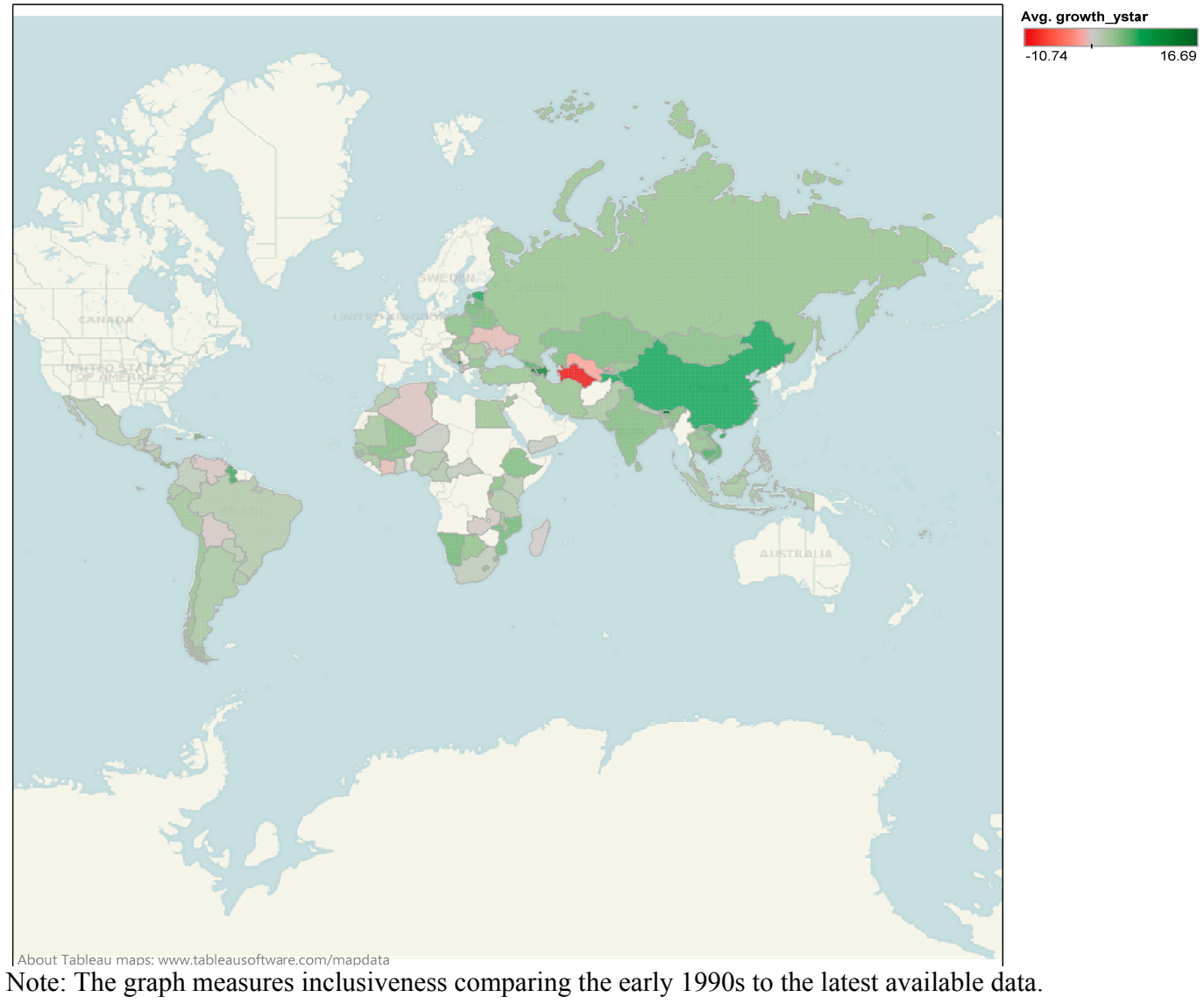


Figure A2. Inclusive Growth is in Line with the Absolute Definition of Pro-poor Growth Comparing slope

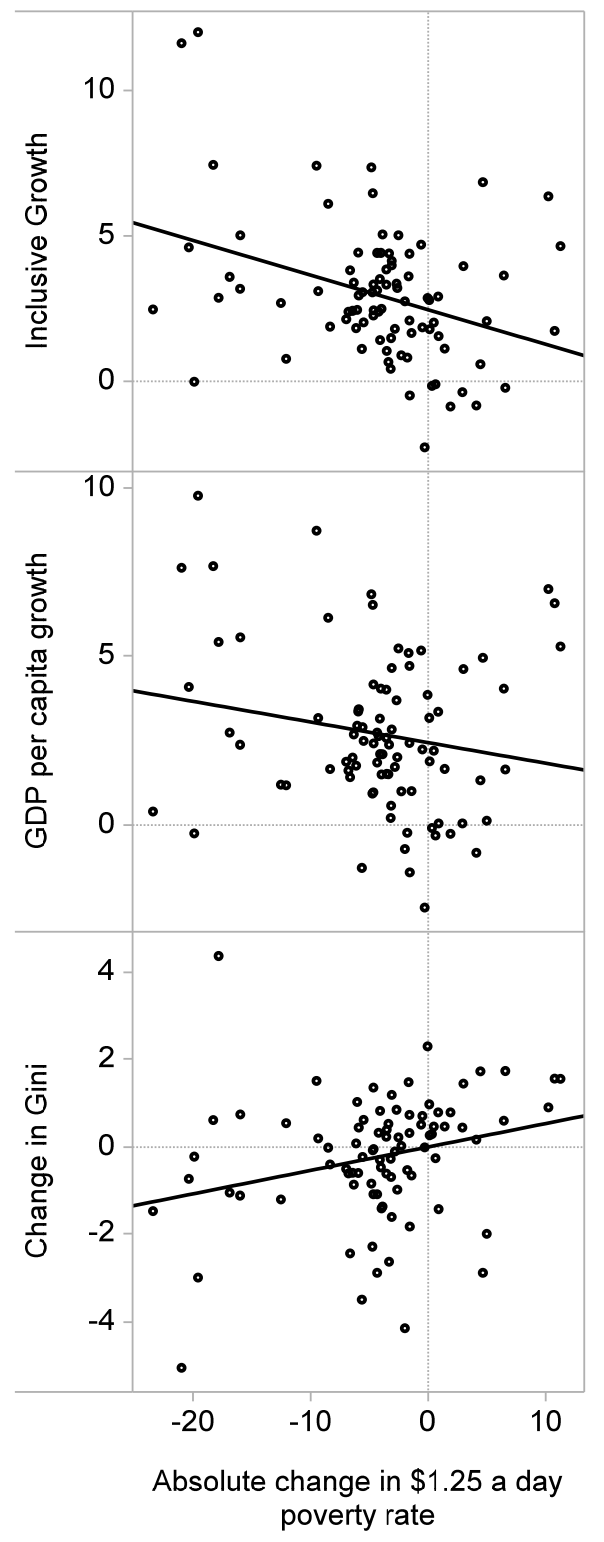

Notes: Headcount rate is percent of population living below $\$ 1.25$ a day. The time period used is the same as in Table A1. Azerbaijan, Malaysia, Maldives and Turkmenistan were significant outliers, they have been dropped. Across all these charts, we use proportionate relative change that is the log difference in $\bar{y}^{*}$ and per capita GDP controlling for time period differences, since there is heterogeneity between countries for the selection of years.

\begin{tabular}{llllll} 
& & & \multicolumn{3}{c}{ Absolute Change in Poverty Rate } \\
& Value & St. Error & t-value & p-value & N \\
Inclusive Growth & -0.11 & 0.03 & -3.42 & $<0.0001$ & 85 \\
GDP/cap Growth & -0.06 & 0.03 & -1.68 & 0.0961 & 85 \\
Change in Gini & 0.05 & 0.02 & 2.45 & 0.016 & 85
\end{tabular}


Figure A3. Indifference Curves for Selected Advanced Economies
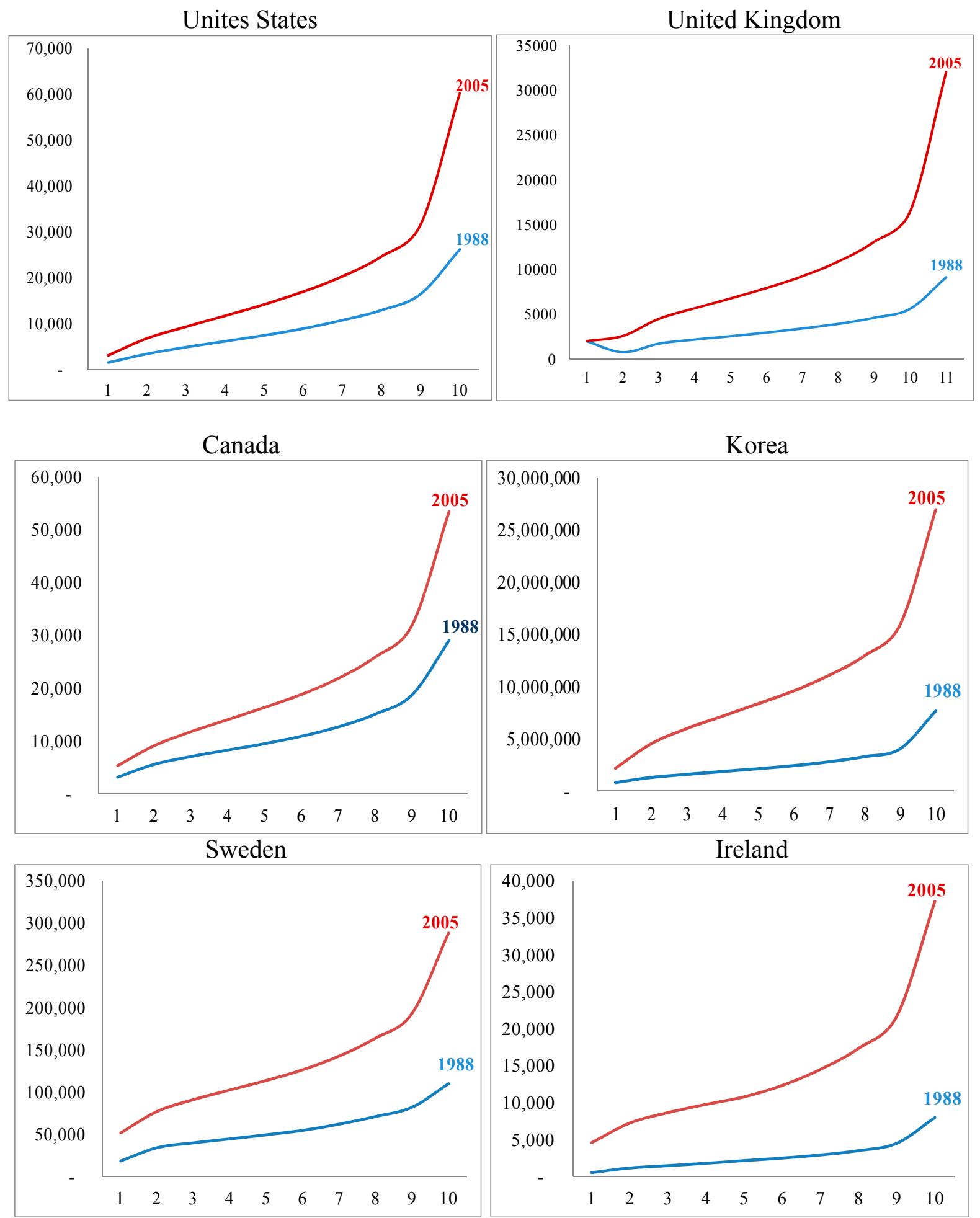
Figure A4. Growth and Equity, the Regional Dimension

The case of Middle East and Central Asia and Western Hemisphere inclusive growth

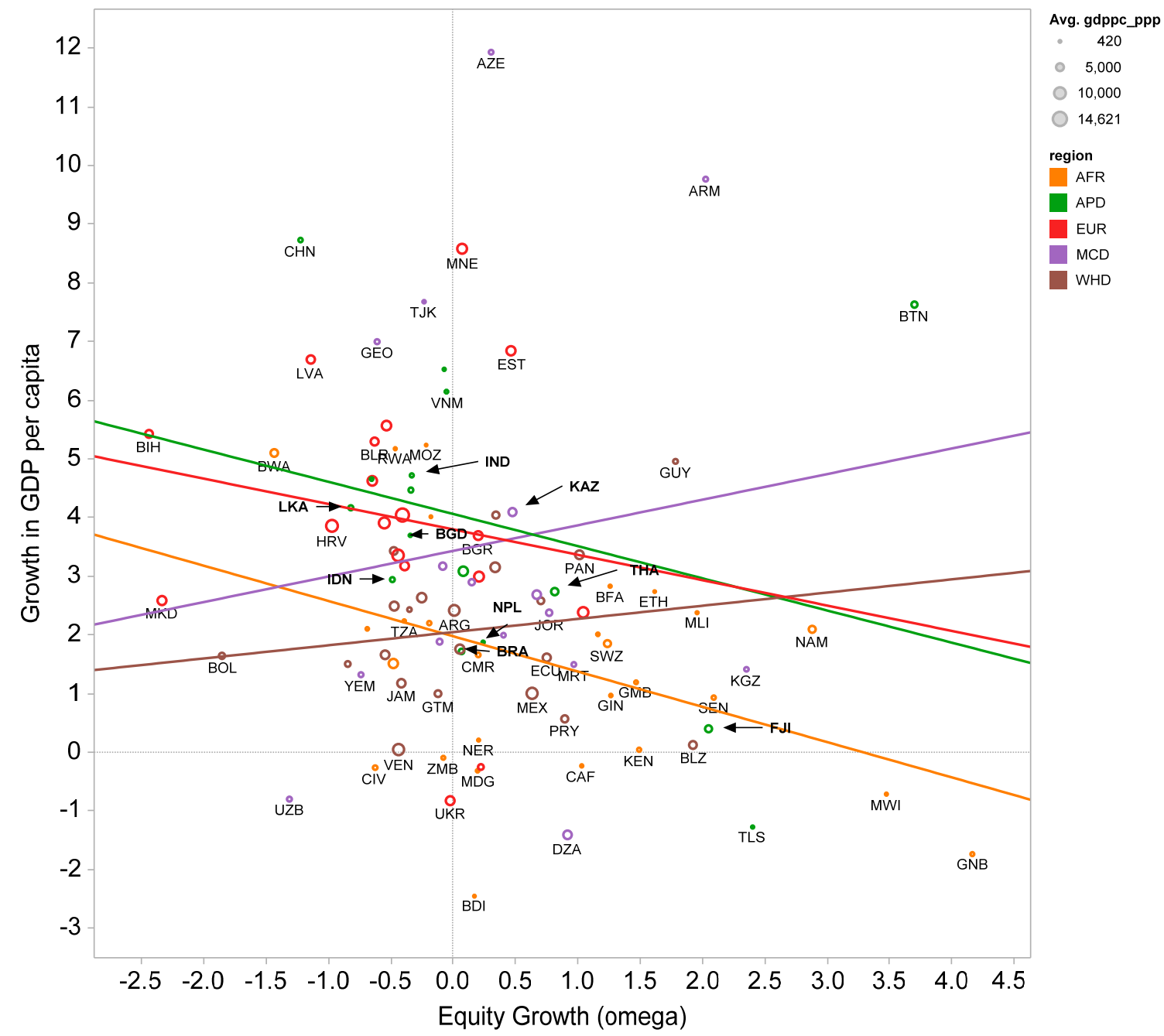

Source: Authors' calculations.

Note: The chart measures proportionate average annual change. The period used is from the early 1990s to the latest available data, see Table A1 for details on time periods chosen. Size represents the initial size of the economy (GDP per capita) i.e. the legend represents countries with PPP GDP per capita below 420, 5000, 10,000 and 14,621 respectively. Different regional codes are denoted by different colors. 
Figure A5. Decomposing Inclusive Growth: Output Growth + Equity $(\omega)$ Growth

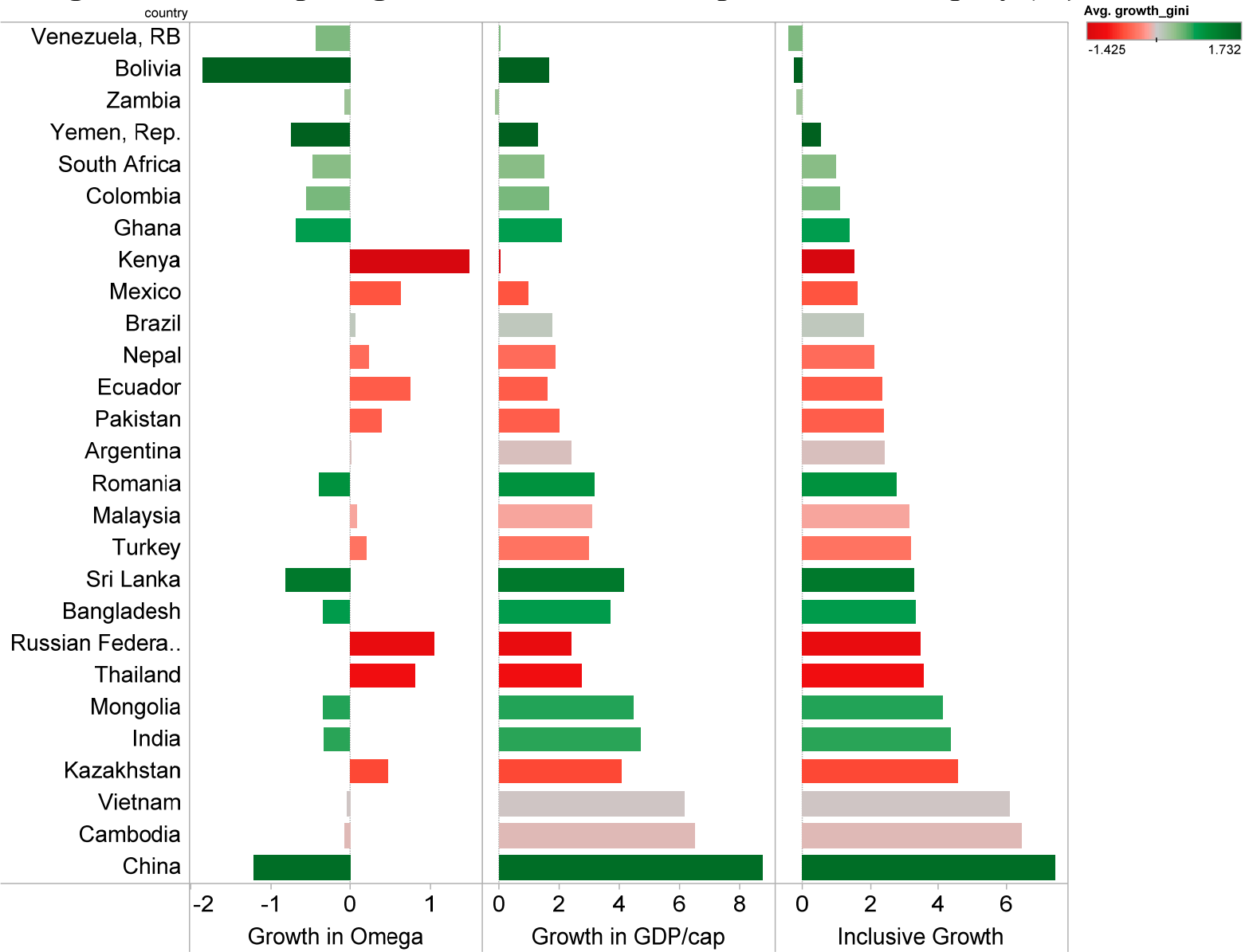

Note: The color spectrum indicates growth in Gini Index, dark green implies increasing inequality, and darker red decreasing inequality. The period used is from the early 1990s to the latest available data, see Table A1 for details on time periods chosen. 
Table A1. Comparing Economic Growth, Inclusive Growth and Equity Across Emerging Markets

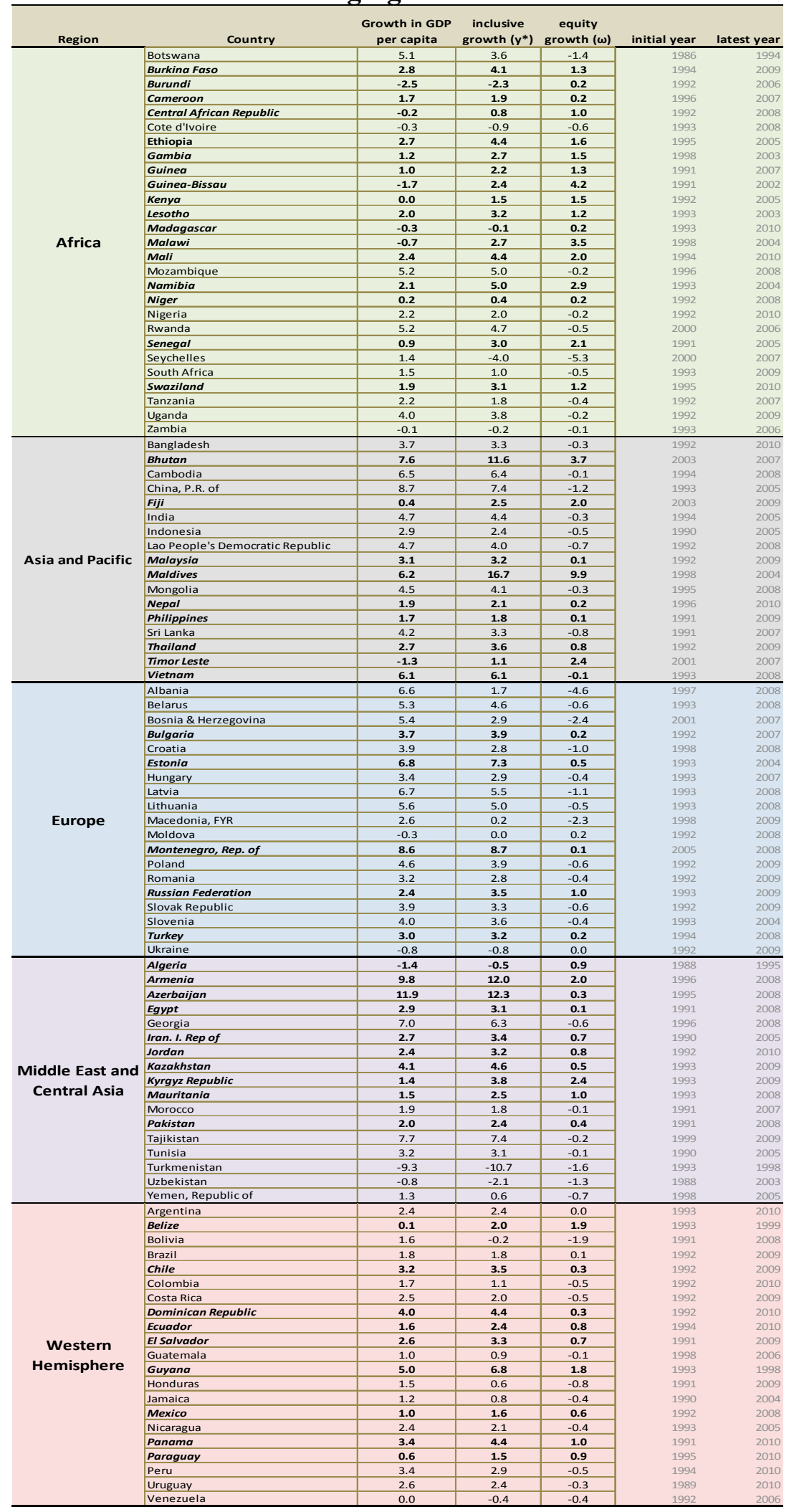


Table A2. Panel Regression: Advanced Economies

Dependent Variable: Growth in $\bar{y}^{*}$ (inclusive growth)

\begin{tabular}{|c|c|c|c|c|c|}
\hline & (1) & (2) & (3) & (4) & (5) \\
\hline lag GDP per capita (logs) & $\begin{array}{c}-0.112^{* * *} \\
(0.0282)\end{array}$ & $\begin{array}{l}-0.104^{* * *} \\
(0.0288)\end{array}$ & $\begin{array}{c}-0.0937^{* * *} \\
(0.0264)\end{array}$ & $\begin{array}{c}-0.128^{* * *} \\
(0.0183)\end{array}$ & $\begin{array}{l}-0.142^{* * *} \\
(0.0421)\end{array}$ \\
\hline Education & $\begin{array}{l}0.0153^{* * *} \\
(0.00509)\end{array}$ & $\begin{array}{l}0.0151^{\star * *} \\
(0.00491)\end{array}$ & $\begin{array}{l}0.0149^{* * *} \\
(0.00419)\end{array}$ & $\begin{array}{l}0.0151^{* * *} \\
(0.00378)\end{array}$ & $\begin{array}{l}0.0187^{* * *} \\
(0.00485)\end{array}$ \\
\hline Trade Openness & $\begin{array}{l}0.00122^{\star * *} \\
(0.000216)\end{array}$ & $\begin{array}{l}0.00134^{* * *} \\
(0.000369)\end{array}$ & $\begin{array}{l}0.00141^{* * *} \\
(0.000319)\end{array}$ & $\begin{array}{l}0.00107^{* * *} \\
(0.000177)\end{array}$ & $\begin{array}{c}0.00114^{* *} \\
(0.000465)\end{array}$ \\
\hline Credit-to-GDP & $\begin{array}{c}-0.0109 \\
(0.00981)\end{array}$ & $\begin{array}{c}-0.0110 \\
(0.00945)\end{array}$ & $\begin{array}{l}-0.00983 \\
(0.00923)\end{array}$ & $\begin{array}{c}-0.0111 \\
(0.00709)\end{array}$ & $\begin{array}{l}-0.00837 \\
(0.00858)\end{array}$ \\
\hline Government Consumption & $\begin{array}{c}-0.00415^{* * *} \\
(0.00140)\end{array}$ & $\begin{array}{c}-0.00418^{* * *} \\
(0.00143)\end{array}$ & $\begin{array}{c}-0.00416^{* * *} \\
(0.00142)\end{array}$ & $\begin{array}{c}-0.00295^{\star *} \\
(0.00124)\end{array}$ & $\begin{array}{l}-0.00529 \\
(0.00365)\end{array}$ \\
\hline Investment & $\begin{array}{l}0.00358^{\star * *} \\
(0.000884)\end{array}$ & $\begin{array}{l}0.00361^{* * *} \\
(0.000886)\end{array}$ & $\begin{array}{l}0.00361^{* * *} \\
(0.000881)\end{array}$ & $\begin{array}{l}0.00350^{* * *} \\
(0.000880)\end{array}$ & $\begin{array}{l}0.00466^{* *} \\
(0.00195)\end{array}$ \\
\hline Inflation & $\begin{array}{c}-0.00839 * * * \\
(0.00185)\end{array}$ & $\begin{array}{c}-0.00816^{\star * *} \\
(0.00178)\end{array}$ & $\begin{array}{c}-0.00848^{* * *} \\
(0.00166)\end{array}$ & $\begin{array}{c}-0.00794^{* * *} \\
(0.00199)\end{array}$ & $\begin{array}{c}-0.0106^{* * *} \\
(0.00325)\end{array}$ \\
\hline Financial Openness & & $\begin{array}{l}-1.90 \mathrm{e}-05 \\
(2.94 \mathrm{e}-05)\end{array}$ & & & \\
\hline FDI & & & $\begin{array}{l}-0.000380 \\
(0.000257)\end{array}$ & & \\
\hline ICT & & & & $\begin{array}{l}0.289^{* * *} \\
(0.0606)\end{array}$ & \\
\hline REER Deviations & & & & & $\begin{array}{c}0.000108 \\
(0.000372)\end{array}$ \\
\hline Constant & $\begin{array}{l}0.227^{* * *} \\
(0.0663)\end{array}$ & $\begin{array}{l}0.195^{\star *} \\
(0.0750)\end{array}$ & $\begin{array}{l}0.159^{\star *} \\
(0.0654)\end{array}$ & $\begin{array}{l}0.190 * * * \\
(0.0413)\end{array}$ & $\begin{array}{l}0.296 * * * \\
(0.0654)\end{array}$ \\
\hline Observations & 254 & 254 & 254 & 254 & 181 \\
\hline R-squared & 0.418 & 0.420 & 0.430 & 0.464 & 0.436 \\
\hline Number of countries & 18 & 18 & 18 & 18 & 17 \\
\hline
\end{tabular}




\section{REFERENCES}

Acemoglu, Daron and David Autor, 2011, "Skills, Tasks and Technologies: Implications for Employment and Earnings,” NBER Working Paper No. 16082 (Cambridge, Massachusetts: National Bureau of Economic Research).

Aizenman, Joshua, Minsoo Lee, and Donghyun Park, 2012. "The Relationship between Structural Change and Inequality: A Conceptual Overview with Special Reference to Developing Asia”, ADBI Working Paper No. 2012.

Ali, Ifzal and H. Hwa Son, 2007, "Measuring Inclusive Growth, “Asian Development Review, Vol. 24, No. 1, pp.11-31.

Anand, Rahul, Saurabh Mishra, and Nikola Spatafora, 2012, "Structural Transformation and the Sophistication of Production,” IMF Working Paper No. 12/59.

Asian Development Bank, 2002, "Growth and Poverty: Lessons from the East Asian Miracle Revisited,” ADB Institute Research Paper No. 33 (Manila).

Barro, Robert J, 2000, "Inequality and Growth in a Panel of Countries," Journal of Economic Growth, Springer, Vol. 5, No.1, pp. 5-32.

Barro, Robert J., and Jong-Wha Lee, 2000, "International Data on Educational Attainment: Updates and Implications,” CID Working Paper No. 042 (Cambridge, Massachusetts: Center for International Development).

Berg, Andrew, and Jonathan D. Ostry, 2011a, "Inequality and Unsustainable Growth: Two Sides of the Same Coin?” IMF Staff Discussion Note 11/08 (Washington: International Monetary Fund). ,2011b, "Equality and Efficiency," Finance \& Development, International Monetary Fund, September 2011, Vol. 48, No. 3.

Barro, Robert J., 1996, “Determinants of Economic Growth: A Cross-Country Empirical Study,” NBER Working Paper No. 5698.

Bosworth, Barry, and Susan M. Collins, 2003, "The Empirics of Growth: An Update," Brookings Papers on Economic Activity, Vol. 2003, No. 2.

Birsdall, Nancy, 2010, "The (Indispensable) Middle Class in Developing Countries; or, The Rich and Rest, Not the Poor and the Rest," Center for Global Development Working Paper 207.

Chaudhuri, Shubham, and Martin Ravallion, 2007, "Partially Awakened Giants: Uneven Growth in China and India," in Dancing with Giants: China, India and the Global Economy, ed. by L. Alan Winters and Shahid Yusuf (Washington: World Bank). 
Calderon C., and L. Servén, 2004, "The Effects of Infrastructure Development on Growth and Income Distribution,” World Bank Policy Research Working Paper 3400.

Commission on Growth and Development, 2008, Growth Report: Strategies for Sustained Growth and Inclusive Development (Washington: World Bank).

Dollar, David, and Aart Kraay, 2003, “Institutions, Trade, and Growth,” Journal of Monetary Economics, Elsevier, Vol. 50, No. 1, pp. 3-39.

Dollar, D., and A. Kraay, 2002, "Growth is Good for the Poor," Journal of Economic Growth, Vol. 7, No. 3, pp. 195-225.

International Monetary Fund, 2007, “Globalization and Inequality,” World Economic Outlook, Chapter 4, October, Washington DC. 2011, Regional Economic Outlook: Asia and Pacific, October, Washington DC.

Hausmann, Ricardo, Jason Hwang, and Dani Rodrik, 2007, "What You Export Matters," Journal of Economic Growth Vol. 12, No. 1, pp. 1-25.

Ianchovichina, Elena, and S. Lundstrom Gable, 2012, "What is Inclusive Growth?” in Commodity Prices and Inclusive Growth in Low-Income Countries, ed. by Rabah Arezki, Catherine Pattillo, Marc Quintyn, and Min Zhu, International Monetary Fund.

Kanbur, Ravi and Michael Spence (eds.), 2010, "Equity in a Globalizing World,” World Bank.

Kakwani, N. 1980, Income Inequality and Poverty: Methods of Estimation and Policy Applications, New York: Oxford University Press.

Kraay, A., 2004, "When is Growth Pro-Poor? Cross-Country Evidence," IMF Working Paper No. 04/47.

Levine, Ross, 2005. "Finance and Growth: Theory and Evidence," Philippe Aghion \& Steven Durlauf (eds.), Handbook of Economic Growth, Edition 1, Volume 1, chapter 12, pp. 865-934.

Lopez, H., and L. Servén, 2004, “The Mechanics of Growth-Poverty-Inequality Relationship,” mimeo. (Washington: World Bank).

Milanovic, Branko, 2010, "Haves and the Have-Nots: A Brief History of Global Inequality," Basic Books.

Mishra, Saurabh, Susanna Lundstrom and Rahul Anand, 2011, "Service Export Sophsitication and Economic Growth," World Bank Policy Working Paper No. 5606.

Okun, Arthur, 1975, Equality and Efficiency: The Big Tradeoff(Washington: Brookings Institution Press). 
Ravallion, M., and S. Chen, 2003, "Measuring Pro-Poor Growth," Economics Letters, Vol. 78, pp. 93-99.

Sala-i-Martin, Xavier, 2006, "The World Distribution of Income: Falling Poverty and Convergence Period," The Quarterly Journal of Economics, Vol. CXXI, May, Issue 2.

Seneviratne, D., and Yan Sun, 2013, "Infrastructure and Income Distribution in ASEAN-5: What are the Links?" IMF Working Paper No. 13/41. 